\title{
The Influence of Principal Leadership and Work Commitment on Professionalism of Primary School Teachers
}

\author{
Ican'; Yasir Arafat'² Destiniar ${ }^{3}$ \\ 1,2,3 Department of Education Management, Universitas PGRI Palembang, Indonesia. \\ ${ }^{1}$ Corresponding Email: icann.bta@gmail.com, Phone Number : 0852 xxxx xxxx
}

\section{Article History:}

Received: Dec 29, 2020

Revised: Jan 11, 2021

Accepted: Jan 30, 2021

Online First: Feb 08, 2021

\section{Keywords:}

Commitmen, Principal

Leadership, Teacher.

\section{Kata Kunci:}

Guru, Kepemimpinan

kepala sekolah,

Komitmen.

\section{How to cite:}

Ican, I., Arafat, Y., \& Destiniar, D. (2021). The Influence of Principal Leadership and Work Commitment on

Professionalism of Primary School Teachers. Edunesia: Jurnal Ilmiah Pendidikan, 2 (2): 333-341.

This is an open access article under the $C C-B Y-N C-N D$ license

\begin{abstract}
This study aims to determine the influence of principal leadership and work commitment to the professionalism of primary school teachers. The formulation of the problem in this study, namely (1) how is the influence of the principal leadership on teacher professionalism?, (2) how is the influence of work commitment on teacher professionalism?, (3) how is the influence between principal leadership and teacher work commitment to teacher professionalism. This study uses a quantitative approach with an ex post facto design. This research is looking for systematic empirical data and in this study the researcher can't directly control the independent variables because the events have occurred and according to their nature can't be manipulated. This study places the influence of principal leadership and teacher work commitment to the professionalism of primary school teachers in Cokroaminoto cluster, Semidang Aji District, OKU Regency. The results of the descriptive analysis show that the performance of the Cokroaminoto cluster primary school teachers in good category of $65.5 \%$, that's, the mean or average score is 61.4155 which in 52-63 interval. The results of the descriptive analysis show that the professionalism of teachers in the professional category of teachers in carrying out their duties is $77.5 \%$. However, there are still teachers whose professionalism is in the quite professional category at $12.0 \%$ and even there are still teachers who are less professional in carrying out their duties by $2.8 \%$, this is reflected in the indicator that teachers do not master the methods and evaluation of learning outcomes. Based on the results of multiple regression analysis, the regression equation line $\mathrm{Y}=18.668+0.260 \mathrm{X}_{1}+0.472 \mathrm{X}_{2}$ is obtained. These results indicate that this positive sign is in accordance with the theory and can be interpreted that the principal leadership and teacher professionalism are good, so the teacher's performance will be good too.
\end{abstract}

Abstrak: Penelitian ini bertujuan untuk mengetahui pengaruh kepemimpinan kepala sekolah dan komitmen kerja terhadap profesionalisme guru sekolah dasar. Rumusan masalah dalam penelitian ini yaitu, (1) bagaimana pengaruh antara kepemimpinan kepala sekolah terhadap profesionalisme guru?, (2) bagaimana pengaruh komitmen kerja terhadap profesionalisme guru?, (3) bagaimana pengaruh antara kepemimpinan kepala sekolah dan komitmen kerja guru terhadap profesionalisme guru?. Penelitian ini menggunakan pendekatan kuantitatif dengan desain ex post facto. Penelitian ini mencari data empirik yang sistematik dan dalam penelitian ini peneliti tidak dapat mengontrol langsung variabel bebas karena peristiwanya telah terjadi dan menurut sifatnya tidak dapat dimanipulasi. Penelitian ini menempatkan pengaruh kepemimpinan kepala sekolah dan komitmen kerja guru terhadap profesionalisme guru sekolah dasar pada gugus Cokroaminoto, Kecamatan Semidang Aji, Kabupaten Ogan Komering Ulu (OKU). Hasil analisis deskriptif menunjukkan bahwa kinerja guru Sekolah Dasar Gugus Cokroaminoto dalam kategori baik $65,5 \%$ yaitu diperoleh mean atau skor rata-rata sebesar 61,4155 yang terletak pada interval 52-63. Hasil analisis deskriptif menunjukkan bahwa profesionalisme guru dalam kategori menjalankan tugasnya yaitu sebesar 77,5\%. Namun demikian masih terdapat guru yang profesionalisme dalam kategori cukup sebesar $12,0 \%$, dan bahkan masih terdapat guru yang ikurang profesional dalam melaksanakan tugasnya sebesar $2,8 \%$, ini tercermin pada indikator bahwa guru kurang menguasai metode dan evaluasi hasil belajar. Berdasarkan hasil analisis regresi berganda diperoleh garis persamaan regresi $Y=18,668$ $+0,260 \mathrm{X}_{1}+0,472 \mathrm{X}_{2}$. Hasil ini menunjukkan tanda yang positif ini adalah sesuai dengan teori dan dapat dimaknai bahwa kepemimpinan kepala sekolah dan profesionalisme guru baik maka kinerja guru juga akan baik. 


\section{A. Introduction}

Education is one aspect that plays a central role in life, according to Law no. 20 of 2003 concerning the national education system. Education is a right that must be obtained by all people, education determines the development of nation and state. Everyone is competing to find knowledge to be used in life. Omeri (2015) states that the priority for national development is to create a society with noble, moral, ethical, cultured, civilized characters based on Pancasila.

One of the important things that cannot be separated from human life is education. Syaifullah (2014) argues that education as a vital means of developing human resources is a need that cannot be separated from human life in educating the nation's life and forming skilled humans in their fields. Leadership is an action taken by individuals or groups to coordinate and give directions to individuals or groups to coordinate and give directions to other individuals or groups who are members of a particular forum to achieve predetermined goals (Suryadi et al, 2020). Competence is a general term for the skills, knowledge and adequate function of a profession. There are two teacher competencies, namely general competence and special competence (Sukamto, 2016).

Sion (2016) said that teachers in carrying out their duties and responsibilities are certainly influenced by various conditions. The conditions referred to are work commitment and job satisfaction. Personnel who have a high commitment, in this case are teachers, the related institutions will produce more productive results. The concept of organizational commitment is important for someone in carrying out their duties and obligations. Commitment is a sense of attachment and loyalty directed by a person towards his place of work.

Ahmad (2013) said that apart from work commitment, the progress of an educational institution is determined by leadership. The principal as a leader has a duty as a driving force to advance the educational institution he leads. Leadership is said to be good and successful if the principal is able to influence all the elements in the institution he leads. Through the strength inherent in his position, the principal must be able to make changes, so that the educational institution he leads becomes a quality educational institution.

Armstrong (2010) states that commitment is "love and loyalty which consists of; (1) unification with the goals and values of the company, (2) the desire to remain with / in the organization, (3) willingness to work hard on behalf of the organization". While Luthans (in Wibowo 2015) defines commitment as: (1) a strong desire to remain a member of a particular organization, (2) a desire to urge efforts at the level on behalf of the organization, (3) a definite belief in certain matters and acceptance towards the values and goals of the organization. In other words, commitment is an attitude that reflects employee loyalty to the organization. Meanwhile, according to Cohen (2003) commitment is a force that binds an individual to an action that is relevant to one or more targets.

Meanwhile, Mus et al (2017) stated that organizations whose members have a higher level of commitment will also show higher performance and productivity with low employee absenteeism and tardiness. This means that the level of commitment possessed by workers affects the work and achievement of organizational goals. Santika and Sudibya (2017) define commitment as a feeling of identification, involvement, and loyalty expressed by workers towards the company. According to them, commitment involves three characteristics: (a) feelings of identification with organizational goals, (b) feelings of involvement in organizational tasks, and (c) feelings of loyalty to the organization. Then, 
Kreitner and Kinicki (Wibowo, 2014) mention commitment as an agreement in doing something for themselves, other individuals, and groups / organizations.

Syaifullah (2014) states that commitment reflects the level of circumstances where individuals identify themselves in the organization and its goals. Thus it is increasingly clear that organizational commitment includes three main dimensions, namely; identification of the goals to be achieved by the organization, the workers 'feelings for their involvement in the tasks that must be carried out in the organization, and the workers' feelings of loyalty to the organization.

Jingping (2015) revealed that teacher commitment is significantly related to student learning outcomes. A teacher with high commitment will have a concern for the task, the needs of students, peers or direct superiors, as well as for school and change. According to Mulyasa (2013) Competence is one of the factors that affect teacher professionalism. Competence is an observable activity that covers aspects of knowledge, skills, values, attitudes, and the stages of their implementation as a whole. Teacher competence is a combination of personal, scientific, technological, social, and spiritual abilities which kaffah form the standard competency of the teacher profession, which includes material mastery, understanding of students, educational learning, personal development and professionalism.

The realization of a quality society is the responsibility of education, especially in preparing students to become subjects who increasingly play a role in displaying their strong, creative, independent and professional excellence in their respective fields (Mulyasa, 2004). Efforts to improve the quality of education are continuously carried out both conventionally and innovatively. The principal as the education leader is the person most responsible for the success of education in his school. The principal is concerned with leadership in carrying out tasks and relationships between people. So the conditions that must be met by someone who is elected or appointed as the principal must have the ability to carry out duties and the ability to foster good relationships with all school personnel (Muhroji, 2004).

Principal leadership in education includes the process of moving, influencing, motivating and directing people in educational organizations / institutions, especially to achieve the goals that have been formulated. Thus it can be concluded that an educational leader in this case is the principal is required to have the ability to guide, mobilize and encourage and direct people in educational institutions, namely achieving educational goals that have been formulated previously (Arifin and Permadi, 2007). In carrying out his leadership, the principal is assisted by a deputy principal (Herabudin, 2009).

Purwoko (2018) states that with regard to the leadership of the principal as an education administrator, he is responsible for the smooth implementation of education and teaching in his school. Therefore, to be able to carry out their duties properly, the principal should understand, master and be able to carry out activities related to his function as educational administration.

As a manager, the principal must be able to utilize all school resources in order to realize the vision and mission to achieve the stated goals. In addition, the principal must be able to face various problems in school, think analytically and conceptually and must always strive to become an intermediate teacher in solving various problems faced by the education staff who are his subordinates, and strive to make decisions that are satisfactory for all (Mulyasa, 2012). 
Ahmad (2013) also wrote that the appointment of school principals should meet the criteria and requirements, both educational qualifications, seniority of rank, have skills, have managerial abilities, and have professional ethics so that in carrying out the duties they are assigned, they can run optimally as expected. Change is a journey. Persistence in facing challenges and obstacles is one of the strong characteristics of a leader. This means that the principal must be tough, persistent, firm, never give up and have innovations.

As stated in Article 12 paragraph PP. 28 of 1990 that "the principal is responsible for the implementation of educational activities, school administration, fostering other education personnel and the utilization and maintenance of facilities and infrastructure". Leadership is very important in pursuing the desired quality in every school. This can be understood because the smooth implementation of educational tasks is very dependent on the ability of the principal in carrying out his function as a leader in the school. The principal as an education leader must be fully responsible for the smooth implementation of education and learning in schools. Therefore, the principal has an important role and heavy responsibility, so that it requires high skills in various fields, especially in the professions that are carried out as leaders and managers in the implementation of the learning process in schools (Syaifullah, 2014).

Yuliana (2014) argues that teachers are the most decisive component in the education system as a whole, the main and first teachers. Teachers are always in the strategic spotlight when talking about education issues. Teachers play a major role in education development, especially those held formally in schools. Being a teacher is not an easy job, as some people imagine, by mastering the material and conveying it to students is enough, this cannot be categorized as a teacher who has a professional job, because a professional teacher, they must have various skills, special abilities, loves their job, maintains the teacher's code of ethics, and so on.

Daryanto, (2013) states that the work commitment that is formed will result in a good professionalism. Professional comes from the word profession which has the meaning of a job that demands expertise, responsibility, and loyalty to the job, while the word professional refers to two things, namely the person and the appearance or performance of the person in carrying out their duties or work. There are several factors that influence professionalism, including teacher competence, organizational climate, attitude.

Yuliana (2014) also argues that as a leader in educational institutions, the principal is responsible for all school management activities, involving teachers who are competent in their fields to carry out the assigned tasks. The description of teacher professionalism, when viewed from their academic qualifications, shows that professional teachers are teachers who have completed a bachelor's degree or diploma, have the ability to teach and of course master the material. Strategies in increasing professionalism lead to coaching quality teachers.

\section{B. Method}

The research design is the entire planning procedure and research implementation which includes data collection and data processing procedures that have been determined. In conducting a study, a researcher must compile a research design that is tailored to the type and purpose of the study. In accordance with the research objectives and the nature of the problem to be studied, this study uses a quantitative, descriptive, correlation research design. This study uses a quantitative approach with an ex post facto design. This 
research is looking for systematic empirical data and in this study the researcher cannot directly control the independent variables because the events have occurred and according to their nature cannot be manipulated. This study places the influence of principal leadership and teacher work commitment to the professionalism of primary school teachers in Cokroaminoto cluster, Semidang Aji District, OKU Regency.

The population and sample in this study were the principal and all primary school teachers in Cokroaminoto cluster, Semidang Aji District, OKU Regency, totaling 77 teachers. The details of the study population can be seen in the following table.

Table 1. Research population

\begin{tabular}{cll}
\hline No & Names of primary school & Total of teachers \\
\hline 1 & SD Negeri 106 OKU & 11 teachers \\
2 & SD Negeri 108 OKU & 15 teachers \\
3 & SD Negeri 109 OKU & 8 teachers \\
4 & SD Negeri 110 OKU & 15 teachers \\
5 & SD Negeri 111 OKU & 17 teachers \\
6 & SD Negeri 112 OKU & 11 teachers \\
Total & & $\mathbf{7 7}$ teachers \\
\hline
\end{tabular}

Data collection techniques used in this study consisted of questionnaires, interviews and observations. The questionnaire was intended to collect data on teacher leadership, discipline, motivation and performance. Meanwhile, the interview is intended to capture data on the four research variables that cannot be collected using a questionnaire technique. The completeness of the data is also supported by observation.

In the preparation of the instrument used from the Likert Rensis model, namely with the options strongly agree (SA), agree (A), enough agree (EA), disagree (D), strongly disagree (SD). Each option is given a weight ranging from 5 to strongly agree to a weight of 1 for the option strongly disagree. Indriantoro (2002) categorizes the nature of the data into an interval scale. The population in this study were all seventh grade students of SMPK Santo Aloysius Lengko Ajang, Golo Wangkung Village, Sambi Rampas District, East Manggarai Regency, totaling 40 students. Since the population of 40 students was relatively small, all students were sampled in this study.

\section{Result and Discussion}

\section{The Influence of Principal Leadership $\left(X_{1}\right)$ on Teacher Performance $(Y)$}

The results of the descriptive analysis show that the performance of the Cokroaminoto primary school teachers is in good category of $65.5 \%$, namely the mean or average score of 61.4155 which lies in 52-63 interval. However, there are still teachers whose performance is in sufficient category which shows that they are not optimal in teaching and carrying out their professional duties by $15.2 \%$ in sufficient category, according to the results of the data there is an indicator of ability to analyze learning outcomes and the ability to arrange improvement and enrichment programs for students. Meanwhile, the results of the descriptive analysis of the principal leadership showed good or $71.8 \%$.

There is an effect of principal leadership on teacher performance by $25.8 \%$, and this influence is smaller than the professionalism of teachers, which is $39.4 \%$. The influence of 
principal leadership on teacher performance shows a positive and significant regression coefficient. The principal has a heavy responsibility as a leader in his school with regard to human resource management, namely the teachers he leads. This means that if the principal's leadership is good, the teacher's performance will increase. This result is in accordance with the theory or opinion of the Ministry of Education and Culture in management of primary schools (1995), explaining that "educational leadership is the principal ability to exert influences that can cause teachers to be moved to carry out tasks and activities together in achieving educational goals efficiently and effectively ". Thus the leadership of principal who is effective in leading the organization, in this case the primary school of Cokroaminoto cluster, Semidang Aji District, will increase teacher performance. This is evidenced by the results of the regression analysis that the principal leadership coefficient is positive.

\section{The Influence of Teacher Professionalism $\left(X_{2}\right)$ on Teacher Performance $(Y)$}

The results of descriptive analysis show that the professionalism of teachers in professional category of teachers in carrying out their duties is $77.5 \%$. However, there were still teachers whose professionalism was in the quite professional category at $12.0 \%$, and there were even $2.8 \%$ teachers who were less professional in carrying out their duties, this is reflected in the indicator that teachers lacked mastery of methods and evaluation of learning outcomes. The professionalism of primary school in Cokroaminoto teachers who belong to the professional category is driven by a need for encouragement and efforts to increase their competence, which in turn leads to an achievement, namely performance.

There is a positive influence of the teacher professionalism variable on performance, which is $39.4 \%$. The regression coefficient which is positive, means that the more professional a teacher is in doing his job as a teacher, his performance will increase. The primary school teachers of the Cokroaminoto Group of Pengandonan District are in the professional category, this is in accordance with the demands of the Minister of National Education Regulation Number 16 of 2007 regarding the qualifications and competencies of educators that teachers must have professional competence. These results are also in accordance with the desired theory, namely that teachers who are professional in their duties will increase their performance, because they carry out tasks according to their expertise. Professional teachers will always work hard to solve all the problems faced in the hope of achieving better performance.

\section{The Effect of Principal Leadership $\left(X_{1}\right)$ and Teacher Professionalism $\left(X_{2}\right)$ on Teacher Performance (Y)}

Based on the results of multiple regression analysis, the regression equation line $Y$ $=18.668+0.260 \mathrm{X}_{1}+0.472 \mathrm{X}_{2}$ is obtained. These results indicate that this positive sign is in accordance with the theory and can be interpreted that the principal's leadership and teacher professionalism are good, so the teacher's performance will be good too.

The results of the regression line equation can also be interpreted as follows.

a. This constant which is positive indicates that if the two independent variables are not there, the teacher's performance is 18.668. If the principal leadership variable increases by one point, the teacher's performance will increase by 0.260 , assuming that the teacher professionalism variable is constant. 
b. If teacher professionalism increases by one point, teacher performance will increase by 0.472 , assuming the principal leadership variable is constant.

The influence of principal leadership on teacher performance shows a positive and significant regression coefficient. The effect of the principal leadership and teacher professionalism variable on teacher performance was $43.8 \%$. The effect of teacher professionalism on teacher performance is $39.4 \%$, this influence is greater or dominant, this is because teachers are increasingly professional in carrying out their professional duties as teachers, their performance will increase. In Permendiknas Number 16 of 2007 concerning educational qualifications and competencies, teachers must have professional competence. These results are also in accordance with the desired theory, namely that teachers who are professional in their duties will increase their performance, because they carry out tasks according to their expertise. Professional teachers will always work hard to solve all the problems faced in the hope of achieving better performance. The demand for professional teachers will improve their performance and lead to the quality of education as a whole. This is also a challenge and an anticipation in facing globalization that teachers must be professional.

Looking at education as a system, teacher performance cannot be separated from the leadership of the principal in terms of hadmaster and top management in managing schools and empowering teachers. The better the principal leadership in empowering teachers, the teacher performance will increase. In actual fact, what affects teacher performance is not only the principal's leadership and teacher professionalism, there are many other and very complex factors, therefore, other factors outside of this research model that affect teacher performance by $56.20 \%$. Factors outside the regression model and this study, for example, school culture, supervision by the principal of work motivation, job satisfaction, pedagogical competence and so on were not studied.

\section{Conclusion}

Based on the results of descriptive statistical analysis of teacher performance variables, it was obtained a mean of 61.4155 in the good category or $65.50 \%$, the leadership of the principal obtained a mean of 58.8028 in the good category or $71.80 \%$ and the professionalism of teachers obtained a mean of 58.0915 in professional category or $77.5 \%$ at the Cokroaminoto cluster primary school.

There is a positive and significant influence of school principal leadership on teacher performance by $25.80 \%$. This positive effect means that if the principal's leadership is getting better, the teacher's performance will increase. There is a positive and significant influence of teacher professionalism on teacher performance of $39.40 \%$. This positive effect means that if the teacher becomes more professional in carrying out their duties, the teacher's performance will increase.

There is a positive and significant influence of principal leadership and teacher professionalism on teacher performance of $43.80 \%$. This positive effect means that if the leadership of the principal and teachers are more professional in carrying out their duties, the teacher's performance will increase. The ability to write poetry using picture media in students of SMPK Santo Aloysius Lengko Ajang class VII as a whole is classified as good with an average achievement of $77.47 \%$. The number of students who completed was 31 people with a percentage of $77.5 \%$. Meanwhile, there were 9 students who did not complete with a presentation of $22.5 \%$. The use of image media in poetry writing has a very good influence on students' writing skills. Students' enthusiasm, creativity, and 
imagination can be seen in the learning process in the classroom. Suggestions to parties who have a direct or indirect connection in this learning activity.

\section{References}

Ahmad, S. (2013). Faktor Penentu Keberhasilan Kepala Sekolah. Penelitian Dan Evaluasi Pendidikan Tahun 17, No. 1

Amstrong, M. (2010). Manajemen Sumber Daya Manusia. PT Elexmedia. Komputindo. Jakarta. Anggit Astianto

Cohen. (2011). Assesment Teknik Non Tes dalam Perspektif BK. Komprehensif. Jakarta : PT Gramedia Pustaka Utama

Daryanto. (2013). Inovasi Pembelajaran Efektif. Bandung: Yrma Widya

Herabudin. (2009). Administrasi Dan Supervisi Pendidikan. Bandung: Pustaka Setia

Jingping, S. (2015). Conceptualizing The Critical Path Linked By Teacher Commitment. Journal of Educational Administration, 53 (5), pp. 597624. https://doi.org/10.1108/JEA-05-2013-0063

Mulyasa. E. (2012). Manajemen Pendidikan Karakter. Jakarta: PT. Bumi Aksara

Mulyasa. E. (2013). Pengembangan Dan Implentasi Pemikiran Kurikulum. Bandung: Rosdakarya

Mus, A., Koemono, T., \& Wulani, F. (2017). Pengaruh Motivasi Kerja dan Komitmen Organisasional Terhadap Kepuasan Kerja Pada Perawat Rumah Sakit Umum Daerah Bobong. Kajian Ilmiah Mahasiswa Manajemen, 6 (1), pp. 1-10. http://journal.wima.ac.id/index.php/KAMA

Omeri, N. (2015). Pentingnya Pendidikan Karakter Dalam Dunia Pendidikan. Jurnal Manager Pendidikan, 9 (3), pp. 464-468.

https://ejournal.unib.ac.id/index.php/manajerpendidikan/article/view/1145

Purwoko, S. (2018). Pengaruh Kepemimpinan Kepala Sekolah, Komitmen Guru, Disiplin Kerja Guru, Dan Budaya Sekolah Terhadap Kinerja Guru SMK. Jurnal Akuntabilitas Manajemen Pendidikan, 6 (2), pp. 149-162.

https://journal.uny.ac.id/index.php/jamp/article/view/8467

Santika, P.B., \& Sudibya, G.A. (2017). Pengaruh Kelelahan Emosional Terhadap Kepuasaan Kerja dan Komitmen Organisasional. E-Jurnal Manajemen, 6 (2), pp. 634662. https://ojs.unud.ac.id/index.php/Manajemen/article/view/26247

Sion, H. (2006). Hubungan Antara Komitmen Dan Kepuasan Kerja Guru Dengan Performans mengajar Guru SDN Di Daerah Terpencil. Jurnal Ilmu Pendidikan, 13 (1), pp. 51-55. http://journal.um.ac.id/index.php/jip/article/view/63. 
Sukamto, Y., \& Pardjono. (2016). Pengaruh Kompetensi Guru, Komitmen Kerja Dan Motivasi Kerja Terhadap Kinerja Guru SMP Andalan Di Sleman. Jurnal Penelitian Ilmu Pendidikan, 9.(2), pp. 165-178.

https://journal.uny.ac.id/index.php/jpip/article/view/12917

Suryadi., Nurhattati., S., Fransiskus., F., Kemal, I., \& Rachmadtullah, R. (2020). How Is The Relationship of Self-Concepts To The Social Competence Ability Of Elementary School Teachers. Journal of Advanced Research in Dynamical and Control Systems, 12 (6), pp. 2782-2787.

https: / /jardcs.org/archivesview.php?volume=3\&issue=36\&page=12

Syaifullah. (2014). Konsep Pendidian Jerman Dan Australia. Jurnal Ilmiah Peuradeun, 2 (2), pp.261-286.

https://journal.scadindependent.org/index.php/jipeuradeun/article/view/34

Yuliana. (2014). Metodologi Penelitian Kualitatif. Bandung: PT. Remaja. Rosdakarya. 